\title{
Implementing Local Government Strategies: A Framework for Action
}

\author{
Emanuele Padovani ${ }^{1}$, David W. Young ${ }^{2} \&$ Alexander Heichlinger ${ }^{3}$ \\ ${ }^{1}$ Department of Management, School of Economics and Management, University of Bologna, Italy \\ 2 (Emeritus) Questrom School of Business, Boston University, United States \\ ${ }^{3}$ European Institute of Public Administration, Barcelona, Spain \\ Correspondence: Emanuele Padovani, Department of Management, University of Bologna, Forlì Campus, \\ piazzale della Vittoria 15, Forlì FC 47121, Italy. E-mail: emanuele.padovani@unibo.it
}

Received: October 19, 2017

Accepted: February 21, 2018

Online Published: March 18, 2018

doi:10.5539/ijbm.v13n4p73

URL: https://doi.org/10.5539/ijbm.v13n4p73

\begin{abstract}
To implement its strategy, a local government (LG) can use six interrelated activites, which we call the Six Cs. These activities comprise coalition building, citizen involvement, conflict management, compensation and rewards, cross-unit collaboration, and control. Each activity is related to one of Chester Barnard's classic three functions of the executive (communication, coordination, and commitment to purpose). The research was based on in-depth investigations of seven European cities that had received an award for high performance by the European Institute of Public Administration (EIPA). A multiple case study "action research" methodology was used. Although each city had a different strategy, each had used the Six Cs in concert to make its strategy a reality. The Six-C model constitutes a framework that can be used by any city to help implement its strategy. Although there is no "cookbook solution" for using the Six Cs, they nevertheless constitute a conceptual framework that an LG's management team can use to think about how it will move toward its strategic vision. An LG that wishes to achieve its strategy must think about how it will employ the Six Cs in a coordinated way. The central issues are not only the specifics of each $\mathrm{C}$ but how each matches and is aligned with the other five in order to assist the city to move toward its strategic vision.
\end{abstract}

Keywords: strategic management, strategy implementation, local/city governments, public management

\section{Introduction}

Local governments (LGs) play a key role in any society. To be successful, they must balance their roles as investors, purchasers, and employers, in addition to service deliverers and policy- makers (Pröhl \& Heichlinger, 2009). They invest in a variety of infrastructure projects designed to improve the functioning of their communities. They purchase some services, such as trash collection and disposal, rather than carrying them out with their own employees. At the same time, most have a sizeable workforce to provide citizens with responsive and well-managed services, whether these be for obtaining a dog license, paying a parking fine, or extinguishing a fire. In addition, many cooperate with other governments (usually central governments and/or regional governments) to provide such basic services as transportation, infrastructure, and public safety.

To better understand the managerial activities that LGs use to implement their strategies, the research team examined seven selected LGs in seven European countries: Bilbao (Spain), Birmingham (United Kingdom), Mannheim (Germany), Milan (Italy), Tallinn (Estonia), Tampere (Finland), and Trondheim (Norway). All seven had a reputation for being well managed, since all had received European awards in recognition of their being high performing organisations. The seven cities have been examined in a previous research project and publication related to local public management excellence (Bosse et al., 2013).

Our approach is to examine, develop and apply a conceptual model leading to the identification of six activities that these LGs used in implementing their strategies. These activities, which we call the "Six-C" Model, comprise (1) coalition building, (2) citizen involvement, (3) conflict management, (4) compensation and rewards, (5) cross-unit collabortion, and (6) control. These Six Cs can be used by other LGs to assist in the implementation of their strategies. By doing this, our aim is to elaborate the previous analytical framework and seven-steps model leading to public management excellence.

In the next section we discuss the theoretical context of our study. We then describe the methodology we used. 
After presenting summaries of the strategies of the seven LGs, we discuss our Six Cs framework. Conclusions are contained in the last section.

\section{Theoretical Context and Literature Review}

The activities that comprise the Six Cs can best be viewed in the context of Barnard's Functions of the Executive (1938). Barnard's classic definition of an organization as "a system of consciously coordinated activities or forces of two or more persons," has been an organizing principle in management for almost 80 years. The two key questions from an operational perspective have always been "What are the activities?" and "How can they best be coordinated?"

Barnard identified three key executive functions: communication, coordination, and commitment to purpose. Porter (1996) put these functions (and the related activities) into an operational context for several for-profit entities, but did not conceptualize them in a way that is useful for managers attempting to bridge the gap between Barnard's broad generalizations and the specific activities that need to take place so that an organization can implement its strategy successfully.

Barnard functions also have been addressed in the public management arena, mainly in light of the New Public Management (NPM) paradigm (Hood, 1991; 1995). The NPM paradigm depicts public sector organizations as lean, effective entities, comprising organizational units that have clear definitions of responsibilities and considerable managerial autonomy, and where unneeded bureaucratic procedures have been replaced by an emphasis on frugal behavior so as to minimize waste. In the NPM paradigm, these organizations are run by public officials who use managerial approaches that have proven successful in the private sector. Quality improvements are ongoing, and include efforts to measure outputs, results and performance, and to benchmark them against external standards (Osborne \& Gaebler, 1992).

For a variety of reasons, including the complex oversight and funding environments in which many LGs operate (Lapsley, 2008), the NPM paradigm effectively constitutes an economic "ideal type," i.e., a state of affairs, akin to a purely competitive market: it is sought in the abstract but never actually attained. In part, the difficulties public sector organizations, including LGs, face in moving toward the NPM paradigm are a result of the political and bureaucratic constraints they face. For instance, the senior members of a municipality's management team often are elected officials who must contend with many external forces and political realities that influence their choices (Kotter \& Lawrence, 1974; Rainey, Backoff, \& Levine, 1976; Mussari, 1994; Pollitt, 2003; Pollitt \& Bouckaert, 2011). If a new program must be initiated for political reasons, for example, it quite likely will not receive a rigorous financial feasibility analysis. In addition, many programmatic objectives - such as "adequate" police protection or an "appropriate" fire response time - are difficult to define and measure, let alone benchmark (Hatry, 2006; De Bruijn, 2002; Poister, 2003). Moreover, the budgeting systems in many LGs are focused on line items, and thus limit senior management's flexibility to shift resources from one activity or program to another during a given fiscal year. As a result, senior management's ability to make midyear budget adjustments when circumstances change or unforeseen needs emerge is highly constrained.

The research project also can be viewed in the context of "public value." According to Moore (1995), increasing public value ". . . equates managerial success in the public sector with initiating and reshaping public sector enterprises in ways that increase their value to the public in both the short and the long run." However, similar to Barnard's executive functions, "public value" is ellusive and amorphous. The concept, while important, provides little practical guidance to an LG's decision makers (both managers and elected officials) in implementing an LG's strategy. Indeed, as Mintzberg et al. (2009) suggest, strategic management is a dynamic process, in which formulation and implementation are entangled and involve a multitude of actors. Moreover, large and mature LGs face a variety of pressures that require constant attention to the strategic change process (Pettigrew \& Whipp, 1991; Pettigrew et al. 1992). As a result, there can be diverse patterns of change based on a given LG's context (Garud \& Van de Ven, 2006).

Similarly, a focus on improving efficiency and effectiveness (a key feature of the NPM Paradigm), along with the application of ideas from private sector organizations to public sector ones, has led to a focus on strategic management. Literature on strategic management in the public sector began in the 1980 s, mainly in reaction to external shocks and increasingly volatile environments with resource constraints, similar to competitive market environments in the private sector (Montanari and Bracker, 1986; Ferlie, 1992; Ferlie and Ongaro, 2015).

While several studies address diverse strategic management approaches in public sector organizations, such as the adaptation of corporate entrepreneurship (Kearney and Meynhardt, 2016), few have addressed strategy implementation in LGs, per se. For example, a study by Andrews et al. (2006) suggested that strategic content matters because it affects organizational performance. Their analysis of 119 English LGs led to the conclusion 
that organizational performance is positively associated with innovative LGs that are pioneers in the field, and perhaps innovation award winners. These LGs were considered to be pro-active risk takers. Those that sought "new markets," i.e., attempted to serve new groups of citizens, were more successful than those that did not. By contrast, poor (or worsened) organizational performance was associated with LGs that were "reactors," i.e. ones that did not possess a coherent strategy or where a strategy was lacking. While this study seemed to demonstrate that LGs that put particular emphasis on strategy implementation were more likely to perform well, it was limited to one national context and did not provide a model that could help other LG decision makers implement their strategies.

Based on a case analysis in an African LG, Buluma, Keror \& Bonuke (2013) singled out the challenges of strategy implementation. They argued that technical support to foster coordination and communication is important, as well as other key factors. Employees need to be trained on the various matters related to strategy implementation, and should be involved in decision-making by developing an inclusive approach from strategy development to its evaluation. Also financial management is key. Similarly, a study of five Australian city councils with similar e-government strategies concluded that effective management of the change process is of critical importance (Hossan et al., 2011). In particular, employees must be involved at the early planning stage so that they would accept additional workloads. Effective communication, feedback, recognition of effort and highlighting the potential benefits of strategy implementation are also considered crucial. Again, while these two qualitative studies are instructive and offer consistent results in two different national contexts, they fail to provide a framework for action.

Employing a Delphi method on cross-national (Australia, Sweden, Spain, and the United States) set of case studies, Pina et al. (2011) focused their research on the factors affecting the strategy implementation process. Their 23 best-practice cases suggest that, although different implementation strategies were followed, three facilitating factors were present in all cases. First, the involvement of personnel was crucial to achieving cultural change. Second, a sense of priority and urgency, and not previous experiences and consultancy services, was important. Third, adaptation of the organization to strategic management was obtained by efforts focused on change management. While these factors are interesting, they do not tell us much about the actual patterns or activities needed to implement a strategy. Similar to Barnard's executive functions, they do not provide much in the way of specific guidance to an LG management team charged with making the municipality's strategy a reality.

It was in the context of these challenges and limitations that the research project examined the seven cities. The goal of the research team was to identify some of the specific managerial activities that the seven LGs used to implement their strategies, and to conceptualize them in a way can assist other LGs with their strategy implementation efforts.

\section{Methods}

An "action research" methodology was used (Kaplan 1998). There is considerable support for this approach (Ragin, 1992; Stake, 1995; Yin 2002; Alexander and Bennett, 2005; Gerring, 2006; Hancock and Algozzine, 2006) when the goal is to understand the workings of a complex social system, in this case a city government. Our study also is consistent with Mintzberg, Ahlstrand, \& Lampel's (2009) school of thought which claims that gaining high descriptive validity requires focusing on a small number of intensively analyzed organizations rather than on the quantitative modeling of a large data set (Bernard, 1957; Ferlie \& Ongaro, 2015).

The seven cities were selected largely because each had been recognized within the European Public Sector Award (EPSA) scheme for 2009 and 2011. This award is given bi-annualy by the European Institute of Public Administration, the leading centre of European learning and development for the public sector, and is supported by several European countries and the European Commission (Note 1) The project's objective was to identify the activities that an LG can undertake to achieve an effective and efficient implementation of its strategy. This "best-practices approach," relying on the selection methodology used by EPSA, allowed us to consider these cities as innovative organization - ones considered to be proactive risk-takers that were undertaking organizational responses to new circumstances (Miles \& Snow, 1978).

According to the EPSA award criteria, the seven cities received their awards - among others-in view of their innovation and impact, as well as the transferability of their approaches to other LGs. The cities also included a wide geographical scope, representing the administrative traditions and systems (Kuhlmann \& Wollmann, 2014) of the Continental European Napoleonic model (Bilbao, Spain and Milan, Italy), the Anglo-Saxon model (Birmingham, UK), the Continental European federal model (Mannheim, Germany), the Central Eastern and South Eastern European model (Tallinn, Estonia), and the Scandinavian model (Tampere, Finland and 
Trondheim, Norway). All cities with the exception of Tallinn belonged to the group of "second tier cities," i.e., non-capital cities whose economic and social performance play an important role in their national economies (Note 2).

Key managers in each city were interviewed to discuss their strategies and action plans, as well as to identify their approaches to achieving their plans. The seven city representatives attended a kick-off meeting of the project where the research concept, the road map, and the project's milestones were presented, discussed and agreed upon.

Several meetings were organized in each city to support the fact-finding and information-gathering process. In addition, working meetings took place to present, discuss, verify and validate the findings and conclusions. This process of data collection, together with the cities' EPSA applications, the summary notes from the EPSA assessment, and the onsite visits and reports (where applicable) formed the main sources for the analysis. (Note 3)

\section{The Seven Strategies}

While one might think that the strategy of any LG would be about the same as any other, that was not the case. Each of the seven LGs had a different overarching strategy that guided its development for a ten-year period, and each had a series of mid-term action plans. The seven cities, their strategies, and their action plans are summarized in Table 1, and are described briefly below. (Note 4)

Table 1. The seven cities and their strategies

\begin{tabular}{|c|c|c|c|c|c|c|}
\hline $\begin{array}{l}\quad \text { Location } \\
\text { Basque } \\
\text { Country, } \\
\text { special statute } \\
\text { region of } \\
\text { Spain }\end{array}$ & $\begin{array}{r}\text { Population } \\
350000\end{array}$ & $\begin{array}{l}\text { Main Issue(s) } \\
\text { Poor urban quality of life; } \\
\text { high level of public debt }\end{array}$ & \begin{tabular}{l}
\multicolumn{1}{c}{ Focal Points } \\
Improved public \\
transportation, safety, and \\
education
\end{tabular} & $\begin{array}{l}\text { Began } \\
\text { Mid } \\
\text { 2000s }\end{array}$ & $\begin{array}{l}\text { Plan Name } \\
\text { Government } \\
\text { Plan 2007- } \\
2011\end{array}$ & \begin{tabular}{l}
\multicolumn{1}{c}{ Results } \\
Debt-free; increased \\
transparency, improved quality of \\
life
\end{tabular} \\
\hline $\begin{array}{l}\text { United } \\
\text { Kingdom } \\
\text { (second most } \\
\text { populous city) }\end{array}$ & 1100000 & $\begin{array}{l}\text { Poor municipal services, } \\
\text { poor financial } \\
\text { management, and high } \\
\text { unemployment }\end{array}$ & $\begin{array}{l}\text { Creating "a City of Vibrant } \\
\text { Urban Villages," improving } \\
\text { job satisfaction for city's } \\
\text { employees, and increasing } \\
\text { efficiency of city operations. }\end{array}$ & 2006 & $\begin{array}{l}\text { Council Plan } \\
2005+\end{array}$ & $\begin{array}{l}\text { Citizen satisfaction rate had } \\
\text { increased to } 85 \text { percent, } 96 \\
\text { percent of invoices were being } \\
\text { paid on time, and the number of } \\
\text { homes with "decent living } \\
\text { standards" had increased from } \\
37 \text { to } 93 \text { percent. }\end{array}$ \\
\hline $\begin{array}{l}\text { Germany } \\
\text { (second most } \\
\text { populated city } \\
\text { of the Baden- } \\
\text { Württemberg } \\
\text { region) }\end{array}$ & 325000 & $\begin{array}{l}\text { Impending deficit of } \\
\text { approximately } € 350 \text { million } \\
\text { (out of an annual budget of } \\
€ 1 \text { billion); shortage of } \\
\text { skilled labor }\end{array}$ & $\begin{array}{l}\text { To grow and develop as } \\
\text { Germany's "most compact } \\
\text { metropolitan, multifaceted, } \\
\text { tolerant and colourful city." } \\
\text { Strategic budgeting. }\end{array}$ & 2008 & CHANGE2 & $\begin{array}{l}\text { Strengthened advisory council } \\
\text { focusing on collaborative policy- } \\
\text { making and greater citizen } \\
\text { involvement. Introduction of a } \\
\text { process in which all employees } \\
\text { participated in strategic dialogues } \\
\text { so as to focus attention on issues } \\
\text { of citizen satisfaction and } \\
\text { austerity. }\end{array}$ \\
\hline $\begin{array}{l}\text { Italy (second } \\
\text { most } \\
\text { populous city) }\end{array}$ & 1350000 & $\begin{array}{l}\text { Aging population, growing } \\
\text { poverty } \\
\text { homelessness,increasing } \\
\text { cost of living, high } \\
\text { unemployment, large } \\
\text { number of immigrants }\end{array}$ & $\begin{array}{l}\text { Involving citizens more fully, } \\
\text { and improving safety }\end{array}$ & 2006 & $\begin{array}{l}\text { Strategic } \\
\text { Plan 2006- } \\
11\end{array}$ & $\begin{array}{l}\text { Simplified means for citizens } \\
\text { contact city government, } \\
\text { improved response time to } \\
\text { complaints, zero-defect results in } \\
\text { terms of corrective actions taken, } \\
\text { increased citizen satisfaction }\end{array}$ \\
\hline $\begin{array}{l}\text { Estonia } \\
\text { (capirtal and } \\
\text { largest city) }\end{array}$ & 420000 & $\begin{array}{l}\text { Decrease in population due } \\
\text { to low birth rate and } \\
\text { emigration of ethnic } \\
\text { minorities. Increase in } \\
\text { private sector small } \\
\text { enterprises. }\end{array}$ & $\begin{array}{l}\text { improvement in the quality of } \\
\text { life and increasing attention } \\
\text { to citizens' needs }\end{array}$ & 2004 & Tallinn 2030 & $\begin{array}{l}\text { More efficient public } \\
\text { administration, implementation of } \\
\text { full e-government procedures, the } \\
\text { development of a successful } \\
\text { information technology incubator, } \\
\text { free public transportation system. }\end{array}$ \\
\hline $\begin{array}{l}\text { Finland (third } \\
\text { largest city, } \\
\text { along with } \\
\text { Greater } \\
\text { Tampere's } \\
490,000 \\
\text { imhabitants) }\end{array}$ & 215000 & $\begin{array}{l}\text { High unemployment, traffic } \\
\text { jams, high dependency of } \\
\text { the economy on just one } \\
\text { organization (Nokia), } \\
\text { changing citizen needs, } \\
\text { and modified } \\
\text { environmental } \\
\text { requirements. }\end{array}$ & $\begin{array}{l}\text { Improved citizen wellbeing, } \\
\text { greater vitality and } \\
\text { competitiveness of the city, } \\
\text { more sophisticated urban } \\
\text { planning, increased internal } \\
\text { employee productivity, and a } \\
\text { stable financial structure. }\end{array}$ & 2001 & $\begin{array}{l}\text { Tampere } \\
\text { Flows }\end{array}$ & $\begin{array}{l}\text { Formation of a culture to involve } \\
\text { citizen in decision making, } 30 \\
\text { percent renewable electricity } \\
\text { used by Tampere city's } \\
\text { properties, reduction of } \\
\text { greenhouse gas emission by } 3 \\
\text { percent annually). }\end{array}$ \\
\hline $\begin{array}{l}\text { Norway (third } \\
\text { populous city) }\end{array}$ & 180000 & $\begin{array}{l}\text { Increasing urban } \\
\text { population growth resulting } \\
\text { in a greatly increased } \\
\text { volume of automobile } \\
\text { traffic. }\end{array}$ & $\begin{array}{l}\text { A } 20 \text { percent reduction of } \\
\text { CO2 emissions, a } 25 \\
\text { percent increase in bus } \\
\text { speed, a } 14 \text { percent } \\
\text { reduction in automobile trips, } \\
\text { a } 15 \text { percent drop in noise } \\
\text { levels, and a } 20 \text { percent } \\
\text { reduction in traffic accidents. }\end{array}$ & 2007 & $\begin{array}{l}\text { The Green } \\
\text { Partnership } \\
\text { Agreement }\end{array}$ & $\begin{array}{l}\text { Increase of buses passengers of } \\
7.5 \text { percent in } 2010 \text {, followed } \\
\text { by } 10.8 \text { percent increase in } 2011\end{array}$ \\
\hline
\end{tabular}

\subsection{Bilbao}

Bilbao is located in the Basque Country region of Spain. In the mid 2000s, the City Council designed a strategic plan and related budgets that comprised ten axes of interventions related to improving several aspects of urban quality of life, including public transportation, safety, and education. At the centre of the strategy was economic austerity and stringency, with the general aim to improve the quality of life while simultaneously increasing efficiency and eliminating the city's outstanding debt. 
By 2013, Bilbao had become one of the few debt-free cities of Spain, completed several public value projects, and increased municipal transparency. Surveys indicated that 90 percent of the residents had a good or very good opinion of quality of life in the city, and 61 percent stated that their own quality of life had improved.

\subsection{Birmingham}

Birmingham is the second most populated city in the UK. In 2006 the city government faced several performance issues: (a) a citizen satisfaction rate of about 50 percent, (b) poor financial management (only two-thirds of invoices were being paid on time), (c) low rated national comparative performance, achieving only one star out of four, and (d) unemployment of over 10 percent.

The "Council Plan 2005+" comprised several actions and targets. The principal areas of focus were improving municipal services, creating "A City of Vibrant Urban Villages," improving job satisfaction for they city's employees, and increasing the efficiency of city operations. By 2013, the citizen satisfaction rate had increased to 85 percent, some 96 percent of invoices were being paid on time, and the number of homes with "decent living standards" had increased from 37 percent to 93 percent.

\subsection{Mannheim}

Mannheim faced a fiscal crisis in 2008 when it became clear that, without corrective action, there would be a deficit of approximately $€ 350$ million (out of an annual budget of $€ 1$ billion) for the fiscal years 2010 to 2013. In addition, the city was facing a shortage of skilled labor but with growing expectations of its citizens for improved quality of municipal services. One indication of its economic condition was that more than 40 percent of the city's budget was allocated to social welfare, mainly child, youth, and family assistance.

In 2008, a new mayor introduced a culture of target and outcome orientation and sustainable finances through fiscal management and strategy-based budgeting, called "CHANGE2" (Note 5). The vision was of a city that would "continue to grow and develop as Germany's most compact metropolitan, multifaceted, tolerant and colourful city."

By 2013, the city had (a) a strengthened advisory council that focused on more collaborative policy-making and greater citizen involvement, (b) improved fiscal sustainability (demonstrated by city budgets that were approved quickly and with minimal modifications), and (c) a process whereby all employees participated in strategic dialogues so as to focus attention on issues of citizen satisfaction and austerity.

\subsection{Milan}

Milan, the second most populous city of Italy, is located in what is considered to be one of the country's wealthiest areas. Nevertheless, in 2006, it faced several socio-economic challenges: (a) an aging population (11 percent were 75 years old or older), (b) growing poverty (17 percent of the population was considered to be poor and 8 percent were homeless), (c) an increasing cost of living, coupled with high unemployment and a high presence of students (about 10 percent of the population), and (d) a large number of immigrants (16 percent of the population).

Among the strategic aims of the mayor (who was elected in 2006) were "listening to the city," involving citizens more fully, and improving safety. He created a "complaint department" (CD) with the goal of creating a network of access so as to enable citizens to get in touch with the municipality easily. The goal was to improve the city's quality of life.

The city achieved several positive results: (a) simplification of means for citizens to get in touch with their government, (b) improved response time to complaints (from over 30 days to 13 days on average), (c) zero-defect results in terms of appropriateness of answers received by citizens and corrective actions taken, and (d) increased citizen satisfaction.

\subsection{Tallinn}

Tallinn is Estonia's capital and largest city. Following its 1991 independence from the Soviet Union, there was a decrease in the number of inhabitants due to a low birth rate and an emigration of ethnic minorities. At about the same time, there was an increase in private sector small enterprises.

The city determined that improvement in the quality of life and increasing attention to citizens' versatile needs were key strategic aims. The city's strategy had two main goals: to create a modern economy and to become a pleasant and safe living environment. The primary objectives were to (a) foster productive and efficient labour markets, (b) provide diverse opportunities and experiences for citizens, (c) develop lifelong learning for citizens, (d) manage social risks, and (e) provide a comfortable, inspiring and environmentally-sound urban space. 
The most important achievements were: (a) a more efficient public administration (measured by a reduction in the time needed to complete main administrative procedures from 15-30 days to 3-5 days), (b) the implementation of full e-government procedures, (c) the development of a successful information technology incubator (resulting in the creation of 160 companies with more than 3200 employees), and (d) a free public transportation system.

\subsection{Tampere}

Tampere is the third-largest city in Finland, and is known as the centre of Finnish industry and knowledge. During the 1980s and 1990s several industries collapsed simultaneously, resulting in an economic recession. In the early 2000s, the city initiated a model of development to redirect growth in an environmentally responsible way.

The city's strategic plan was designed to address the challenges of high unemployment, traffic jams, high dependency of the economy on just one big private organisation (Nokia), changing citizen needs, and modified environmental requirements. The strategy had a multi-pronged focus: (a) improved citizen wellbeing, (b) greater vitality and competitiveness, (c) more sophisticated urban planning, (d) increased employee productivity, and (e) a stable financial structure.

By 2013, the city had made progress on several fronts: (a) the development of a managerial model to address the new challenges, (b) the formation of a culture to involve citizen in decision making, and (c) the creation of positive environmental outcomes ( 30 percent of electricity used by Tampere city's properties was renewable, and greenhouse gas emission had been reduced by 3 percent annually).

\subsection{Trondheim}

Trondheim is the third most populous city in Norway. In 2007, despite efforts made by the central government to support environmental sustainability, it had become clear that Trondheim needed to overcome increased urban population growth and a greatly increased volume of automobile traffic. These problems represented a challenge to the city's ability to stay within the acceptable limits of greenhouse gas emissions determined at the national level.

Trondheim's "Green Partnership Agreement" had a ten-year view (2009-2020), and the following objectives: (a) a 20 percent reduction of $\mathrm{CO} 2$ emissions, (b) a 25 percent increase in bus speed, (c) a 14 percent reduction in automobile trips, (d) a 15 percent drop in noise levels, and (e) a 20 percent reduction in traffic accidents. The city aimed to achieve these goals by improving mass transit infrastructure and service while simultaneously discouraging private mobility (by introducing tolls on major arteries).

Two years after the inception of the new strategy, there had been an increase of buses passengers of 7.5 percent. The next year saw an increase of 10.8 percent.

\section{The Six-C Model}

As indicated earlier, Barnard (1938) identified three general functions that senior management uses to achieve an organization's strategy: communication, coordination, and commitment to purpose. The Six-C Model, shown in Figure 1, unbundles each of these functions into two specific activities that the seven cities used to implement their strategies. (Note 6)

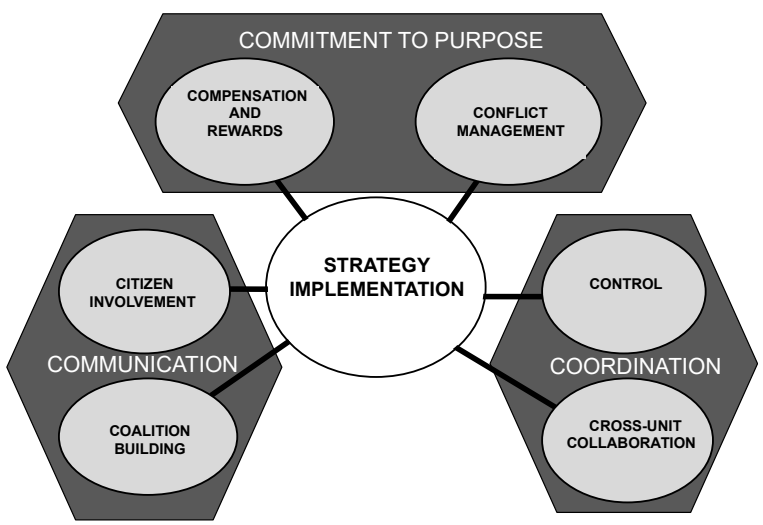

Figure 1. The "Six C" Model 
Attaining each city's strategy required addressing several tricky issues that frequently arise when senior management begins a change effort. In this regard, Kotter (1995) has identified eight steps that a senior management team must take if its desired changes are to be achieved: (1) establish a sense of urgency, (2) form a powerful guiding coalition, (3) create a vision, (4) communicate the vision, (5) empower others to act on the vision, (6) plan and create short-term wins, (7) consolidate improvements and produce still more change, and (8) institutionalize the new approaches. Although these steps may seem evident, Kotter's article contains the ominous subtitle "why transformation efforts fail," suggesting that a change effort frequently is unsuccessful because one or more of the eight steps was not carried out properly.

The seven cities did not follow these steps in the sequence shown. However, all sensed that there was an urgent need to make some changes (Step 1) and each had a vision (Step 3). An important question was how to go about achieving that vision, i.e., to implement the strategy. One key step that each took was to establish a guiding coalition (Step 2). Beyond this, the cities engaged in a variety of activities to both communicate the vision and empower others to act on it (Steps 4 and 5). Several had some short-term wins to build on them (Steps 6 and 7), and to put building blocks in place to institutionalize the changes (Step 8). As discussed below, all of their activities can be classified into one or more of the Six Cs.

\subsection{Communication}

As Figure 1 indicates, Barnard's communication function fell into two categories: coalition building and citizen involvement.

\subsubsection{Coalition Building}

One of the major factors to be considered in creating a successful coalition in an LG is the need to achieve agreement between elected officials and city managers. In many cities, the senior management team can have a difficult time obtaining cooperation from elected officials, mainly because the two groups often have different goals and incentives and different time horizons (Pollitt, 2003). For example, city managers face budgetary constraints coupled with the need to focus on long-term goals, such as infrastructure development. Elected officials, by contrast, often are focused on obtaining a voting majority in the next election, giving them a somewhat shorter-term focus (Pollitt, 2008). In Bilbao, for example, the mayor's goal was "to achieve a better city for all citizens," but to move in that direction he needed to rely on a government team that played a crucial role in transferring the political ideas and strategies of the city's elected officials into concrete actions.

In Birmingham, the motivation to embark on a comprehensive change effort came from the most senior people involved in the city: the Deputy Leader (the second most senior politician in the council), the Chief Executive Officer, and the Corporate Director of Business Change. The Deputy Leader was the overall promoter of the programme and was actively engaged throughout. These three key individuals (the coalition) ensured that the organisational focus on the transformation programme was maintained, particularly during the early years when significant costs were being incurred but benefits were uncertain.

In Tallinn, the Chief Executive Officer of the City Government served as City Secretary for several political governments and thus provided stability and the necessary continuity for such large-scale endeavours. A good working relationship between politicians and administration (the coalition) enabled the successful implementation of many developments. The interaction of the different actors was complemented by an e-Government Committee and separate formal and informal working groups that were set up to discuss the improvement and enhanced accessibility of the respective services.

In Trondheim, a partnership-architecture was established, which included a political steering group consisting of the two elected mayors (City of Trondheim, The South-Trøndelag County) and the National Road Authority's CEO, plus several high level administration officials (the coalition). Trondheim's mayor led the steering group, and the main actors were responsible for the strategic coordination of the initiative. In addition, the institutional arrangement consisted of the governing body (the Liaison Committee), the administrative body (or Project Council), which was in charge of the daily work (and implemented the ideas and recommendations of the Liaison Committee), and one coordinating body (the Executive Committee). All of the different bodies included representatives from the National Public Roads Administration, the county transport authority and the local municipal planning authority, i.e. all three administrative levels.

\subsubsection{Citizen Involvement}

In addition to coalition building, the seven cities also sought ways to involve their citizens in the change effort (the other aspect of communication). Previous studies suggest that an LG's citizens are more inclined to be involved when the LG provides information or engages citizens in consultation (Parrado, Van Ryzin, Bovaird, \& 
Löffler, 2013). Citizens' involvement is more than simply providing information; it extends to consultation and active participation (Martin \& Boaz, 2000). Indeed, although each city took a different approach, all seven made sure that their citizens were actively involved in the strategy implementation effort.

In Bilbao, for example, transparency and accountability were key guiding principles. For instance, the City Council entrusted the Department of Participation and the District Councils to promote and develop their own participation model for citizens. Among other activities, the councils prioritised the investment for annual work and services in the districts. Birmingham, by contrast, put its focus on involving citizens in the city's budgeting process, which included consultation across public and voluntary sectors and special interest groups. The consultations were conducted via online surveys, community meetings, employee briefings, and meetings with the People's Panel and trade unions.

In Mannheim, one of the pillars of the "CHANGE2" project was the improvement of democratic participation via the reform of the city council. The council held three public meetings a year, which were designed to create a direct connection between the citizens and the city's administration. In addition, as part of the budgetary process, qualified citizens (assigned by the political parties), private agencies and churches debated the allocation of the resources and were entitled to propose potential change requests or additional demands. Approximately three to four days were reserved for these public consultations. A wider involvement of citizens was ensured through permanent citywide and district-related projects.

In Tallinn, while the Vision Council did not participate in the daily operations of the city's administration, it was an important tool. Among other things, it offered fresh insights and provided a forum for strategic discussions. Most of the council's members were distinguished scientists or experts in the various related thematic fields.

In Tampere, the mayor met with various interest groups and listened to their views. There was a constant interchange between the city leaders, the businesses, and the universities in an effort to recognise the common challenges and respond to them. This was possible due to an "open conversational" culture. Similarly, in Trondheim, the involvement of the various stakeholders was one of the main features of the city's strategy. There was a high level of public and citizen participation in designing the scheme. Because Greater Trondheim was an important player in the city's strategy, the neighbouring communities also were given a voice in the process.

\subsection{Commitment to Purpose}

Assuring that all actors are committed to the goals of a change effort can be tricky. In part, the failure of a transformation effort often arises because some (often many) people in an organization resist senior management's efforts to implement the change. As a result, in each of the cities, Barnard's "commitment to purpose" required an effort to both manage conflict and develop compensation schemes (not necessarily monetary) that rewarded people for their contributions to the change effort.

\subsubsection{Conflict Management}

Attaining a commitment to the purpose of a change effort often requires identifying the different types of conflict that can exist and devising ways to resolve each of these to the LG's overall best interest. As shown in Table 2, conflict management mechanisms can take many forms, ranging from E-mail exchanges to permanent committees (Young, 2017b).

Table 2. Types of conflict and managing mechanisms

\begin{tabular}{lll}
\hline Type of Conflict & Example & Mechanism \\
\hline Low level, one-time & Scheduling a meeting & Information flows (telephone, E-mail) \\
$\begin{array}{l}\text { Moderate, one-time, } \\
\text { with two perspectives }\end{array}$ & $\begin{array}{l}\text { Determining who will attend } \\
\text { a conference }\end{array}$ & Hierarchy \\
$\begin{array}{l}\text { Moderate, one-time, } \\
\text { with multiple perspectives }\end{array}$ & $\begin{array}{l}\text { Designing and launching a } \\
\text { new product }\end{array}$ & Mediator or mediating department \\
$\begin{array}{l}\text { High, continuing, } \\
\text { with two perspectives }\end{array}$ & $\begin{array}{l}\text { engineering and manufacturing } \\
\text { Capital investment decisions; } \\
\text { production scheduling for } \\
\text { several product managers }\end{array}$ & Permanent cross-disciplinary teams \\
with multiple perspectives & & \\
\hline
\end{tabular}

Source: Young (2017b). 
As this table suggests, the conflict-management mechanism needed depends on the level of conflict it is addressing. Given that appropriate kinds of changes being undertaken by the seven LGs were certain to create considerable conflict, all but one created a permanent cross-disciplinary team. Although the composition of the teams differed, each served the purpose of helping to manage high continuing conflict with multiple perspectives.

In Bilbao, where the level of conflict was perhaps the lowest of all seven, the city used social media (Facebook and Twitter) to create the requisite information flows. It also used a municipal Website, presentations to the press, conferences, and permanent contact with the media and citizens to make the strategy known to a larger public audience. In addition, the city located budget responsibility under the direct supervision of the mayor and in the hands of the CEO, which ensured the needed alignment between the strategic objectives of the government plan and the city's finances. This approach served to minimise resistance to the change effort.

Birmingham developed a business transformation programme (in effect a permanent cross-disciplinary team) that was structured into nine work streams, each of which was further structured into a number of projects. The goal was to enhance resources, skills, support and expertise to deliver the ambitious business transformation plan. As part of this effort, the governance structure coordinated work streams and managed dependencies among them.

Mannheim developed an employee magazine to keep the information flows active. It also conducted an annual employee survey and a quarterly "Climate Check" in which employees gauged the degree of compliance with the "city's guidelines on leadership, communication and cooperation. In addition, the mayor created an internal management consultancy unit (a permanent cross-disciplinary team) that was responsible for the standardisation and quality assurance of the project, its coordination, and its monitoring. He also established a long-term programme management structure that included several new units for promoting leadership, management development, and ultimately conflict management.

Milan created something similar to a task force to address the limited amount of financial resources allocated to the project. The task force (a permanent cross-disciplinary team) brought together staff and IT professionals who had different perspectives, but who collaborated to achieve a satisfactory solution to the challenge.

Tampere held ongoing discussions among city managers and officials to address the risks that came from the potential political opposition and the reluctance of some public officials to commit to the change effort. In addition, the city engaged in ongoing discussions and consultation with committee members, chief shop stewards, municipal office holders, interest groups and citizens.

To engage in external communication, Trondheim moved its main offices to the city centre and introduced car-pooling among the local government staff. This scheme then was adopted by businesses operating in the central business area. The choice of such explicit and visible initiative facilitated the city's communication with its citizens. The city also placed billboards at construction sites describing the projects and their progress and sent notes and articles to local newspapers, both of which advised citizens of the kinds of changes that were going to happen, and displayed results and overall information about the ideas, the goals and the outcomes.

Despite these efforts, Trondheim's mayor encountered many challenges by the city's civil servants ("We do not do things like this..."). To overcome them, he established a high-level political steering group (a permanent cross-disciplinary team) as the initiator and decision-maker of the changes. Since the group had been created by a majority vote of the city council as an integral part of the city's Master plan, it had a clear mandate and the full institutional capacity to act, thereby creating goal congruence.

\subsubsection{Compensation and Rewards}

Pfeffer (1998), in studying the impact of compensation on performance, concluded that there is little evidence to support the idea that an organization's compensation system is an important factor in its success. While he does not disagree with the importance of compensation, he cites employee surveys showing that a pleasant, challenging, and empowered work place often has a greater impact on employee behavior than monetary incentives. Leonard \& Swap (1999) make a parallel argument, emphasizing the importance of employees' passion for work that leads them to lose the distinction between work and play. Similarly, Blanchard \& Johnson (1982) discuss the importance of rewarding the right behavior of employees, giving them feedback, and discouraging undesirable behavior. They make the point that if managers tell employees what is expected of them, praise them for small accomplishments, and set increasingly high standards for rewards, the employees will feel appreciated. Indeed, empirical studies applied to LGs argue that socio-relational motivating factors influence good performance, whereas material incentives play only an incidental role (Anderfuhren-Biget, 
Varone, Giauque, \& Ritz, 2010).

Several of the LGs took similarly creative approaches to rewarding employees and managers for helping to move the city toward its strategic goals. Birmingham's approach was perhaps the most dramatic. The city instituted a semi-annual bonus system for good results - an unusual step for a public sector entity. This approach was consistent with Pfeffer's (1998) findings that, although financial rewards may be of secondary importance, they work best when they take the form of incentive — or contingent — compensation.

While the other cities did not use monetary rewards, per se, each found a way to celebrate good results. In Bilbao, for example, the improvement of the image of public administration, and the resulting increase in trust for the city's actions, no doubt left the city's employees with a sense of satisfaction. Moreover, there was a focus on benefits throughout the transformation process; these were tracked in stages and reported to the involved personnel, thereby giving them feedback on the results of their actions.

Mannheim established a set of target contracts, in which city managers were held accountable for concrete management results. Moreover, there was a high level of personal commitment to achieving the goals. An in-house magazine allowed employees to gauge their degree of compliance with the city's guidelines on leadership, communication, and cooperation. Every employee was polled once per quarter to respond to questions about these three factors.

In Milan, an essential part of the change effort was a team of 26 people who acted as sentinels and facilitated the creation of an organisational network for managing complaints. Moreover, each of the 15,700 employees had his or her own set of performance objectives, thereby permitting each person to assess his or her own performance.

In Tampere, there were performance meetings in which managers discussed with their subordinates on a periodic basis the objectives, progress, and results, as well as planned corrective actions. Individuals needed to be prepared to discuss their approaches to implementing the city's strategy.

\subsection{Coordination}

Barnard's coordination function was carried out through two distinct activities. One was control-related (both financial and non-financial), while the other was more organisational. In all instances, achieving the strategy required collaboration across the existing organisational units, which is a distinct departure from the normal way of doing business in many LGs.

\subsubsection{Cross-Unit Collaboration}

In many LGs, there is a matrix structure, even if only implicit (Padovani \& Young, 2012; Young, 2016: Chapter 7), of programs to be provided on one side and functions or departments on the other side. For example, achieving a programmatic goal of "clean and safe streets" requires efforts from several quite distinct departments: street cleaning, trash collection, road maintenance, and public safety (police and fire). Each department can have a set of objectives that it needs to accomplish so that the city can achieve its overall goal of clean and safe streets. At the same time, the program manager must be sure that these objectives are coordinated in such a way that the overall goal of the program is attained as effectively and efficiently as possible. And, of course, the program's goal is only one of several that the city must consider as part of attaining its overall strategy. Moreover, the manager of the Clean and Safe Streets Program must compete with other program managers for an appropriate portion of the city's budget.

Clearly, an important aspect of coordinating the activities of different departments in the pursuit of a program's goals within its budgetary constraints is monitoring and feedback. In this regard, each city had developed a slightly different variation on the theme.

In Bilbao, once the Government Plan 2007-2011 had been approved, the first strategic budgets were put in place in order to link strategic objectives with budgetary commitments. This permitted subsequent budgetary negotiations to be carried out based on strategic priorities rather than on an incremental basis. At the same time, the city established an Efficiency and Austerity Committee to coordinate for the preparation, coordination and monitoring of its programs.

In Birmingham, the budget for each work stream was allocated on the basis of a business case that needed to demonstrate the benefits compared to the costs and the viability of the whole project. Each business case had to be approved by the city's cabinet before the work stream could commence. This ensured that political control was aligned with the transformation process. In addition, the funding was gradually released by a program board, that monitored the progress, and controlled the various stages of the process. The result allowed the city to coordinate its strategy with its financial capabilities. 
Mannheim developed an integrated management information system (containing both financial and non-financial information) to assist in the coordination of its programs and departments. To assure the continuity of its various programs, the city also developed a "traffic-light" budget monitoring tool which monitored projected revenue increases and savings, and which reported the amount every two months. Changes in status, such as from green to yellow, were brought to senior leaders' attention immediately and triggered remedial action. Again, the result was an ability to coordinate the city's strategy with its financial constraints.

Similarly, Tallinn developed a formal monitoring system that provided an integrated view of financial, performance and customer information. Its annual development monitoring reports provided the next year's revenue forecasts, linking them to development indicators and goals. As an indication of the importance of the matrix structure, the city combined proposals sent by departments and city district administrations into the overall program budget. In addition, monthly budget implementation reports were compiled which included an analysis of revenues and expenditures.

In Tampere, by contrast, strategic objectives were the main focus of the task groups. While there was not a straight linkage between allocated resources and achievement of strategic goals, the financial and non-financial performance indicators were reported together. Moreover, there was a long-term commitment to strategic projects which was reflect in the budget allocations.

\subsubsection{Control}

In both the for-profit and nonprofit worlds, the concept of control has a broad meaning, encompassing the management control structure and the management control process (Young, 2016). Structure comprises the design of what often are called "responsibility centres," or organisational units where a manager is expected to achieve certain budgeted financial and non-financial results. The management control process includes the activities of programming, budgeting, measuring, and reporting.

LGs engage in similar activities although there is considerable more variety than in other organisations (Padovani \& Young, 2012). In this regard, all seven cities made extensive use of control, including the important distinction between programming and budgeting. In addition, they developed methods of measuring and reporting both financial and non-financial results in a timely way so that corrective action could be taken when necessary.

In Bilbao, for example, every municipal area participated in budget preparation based on a draft strategy. Moreover, while programming decisions were discussed aligned to the overall strategy, each department's decision to begin a new program needed to be approved by the mayor's office. Once approval was given, the program was translated into a breakdown of expenditures that flowed into the budgeting phase of the process. Subsequently, during the budget year, managers received both financial and non-financial information to help them monitor their performance.

Birmingham's approach to control included information on customer requirements to enable more effective service delivery. For example, the council's integrated reports provided information on revenue, capital and service performance in a single view. This enabled the council to allocate resources more efficiently and to make strategic decisions on where and how the budget should be spent.

In Mannheim, the control effort focused on both cost and key performance indicators (related to objectives). The system produced a quarterly budget report to the city council as well as to senior management. The continuity of the city's various operations was ensured through its "traffic light" budget monitoring tool.

In Milan, the control system gave senior management the opportunity to identify structural problems. More specifically, it allowed all managers of services that had customers (from utilities to the police department) to have rapid feedback on major weaknesses so as to give them the ability to put corrective actions in place.

Tallinn's control system was marked by a high degree of transparency. For example, the draft of the city's budget, strategies, monthly cash-flow reports, and annual financial reports were available on the public Website. Similarly, in Tampere, periodic strategic and financial reviews were reported and sent to the City Council, whose monitoring took place three times per year in order to detect possible deviations. And in Trondheim, all managers had their own budgets and reported regularly to the Executive Committee. Individual project leaders were responsible for forecasting and spending within their projects.

\section{Conclusions}

The Six-C Model can be used by any city to help it think about how to implement its strategy. In many respects, each of the Six Cs is dependent upon the others. One cannot encourage citizen involvement without a coalition 
that supports it, for example. Nor can good communication substitute for good control, and vice versa.

There is no formulaic approach to using the Six Cs. Each of the seven cities implemented its strategy in a different way, although each used the Six Cs in combination. For example, each had a slightly different approach to exercise control, or to address and manage conflict. Cross-unit collaboration also was situational. Some of the cities undertook the effort within the city boundaries, while others focused on collaboration between the city and other governmental entities.

The approach to compensation and rewards was perhaps the most diverse. Birmingham used financial rewards in terms of extra compensation for good performance, whereas other cities used approaches that gave their employees a sense of satisfaction for their high performance.

In summary, there is no cookbook solution for using the Six Cs to implement an LG's strategy. Rather the Six Cs constitute a conceptual framework. An LG that wishes to achieve its strategy must think about how it will employ the Six Cs in a coordinated way. The central issues are not only the specifics of each $\mathrm{C}$ but how each fits with the other five in order to assist the city to move toward its strategic vision.

\section{References}

Alexander, G. L., \& Bennett A. (2005). Case Studies and Theory Development in the Social Sciences. Cambridge, Massachusetts: The MIT Press.

Anderfuhren-Biget, S., Varone, F., Giauque, D., \& Ritz, A. (2010). Motivating employees of the public sector: Does public service motivation matter? International Public Management Journal, 13(3), 213-246. https://doi.org/10.1080/10967494.2010.503783

Andrews, R., Boyne, G., \& Walker, R. (2006). Strategy Context and Organizational Performance: An Empirical Analysis. Public Administration Review, 66(1), 52-63. https://doi.org/10.1111/j.1540-6210.2006.00555.x

Barnard, C. I. (1938). Functions of the Executive. Cambridge, Massachusetts: Harvard University Press.

Bernard, C. (1957). An Introduction to the Study of Experimental Medicine. New York: Dover Publishing Co.

Blanchard, K., \& Johnson, S. (1982). The One-Minute Manager. New York: William Morrow \& Co.

Bosse J., Heichlinger A., Padovani E., \& Vanebo, J. O. (2013). In Search of Local Public Management Excellence: Seven Journeys to Success. Maastricht, The Netherlands: European Institute of Public Administration.

http://www.epsa2013.eu/files/In_Search_of_Local_Public_Management_Excellence_Seven_Journeys_to_S uccess_2013.pdf

Bradach, J. L. (1996). Organizational Alignment and the 7-S Model. Cambridge, Massachusetts: Harvard Business School Publications.

Buluma, P. I., Keror, I. K., \& Bonuke, J. M. (2013). Institutional Related Factors Affecting the Implementation of Strategic Plans in Local Authorities in Kenya: A Case of Municipal Council of Eldoret. International Journal of Business and Management, 8(10), 81-85. http://doi.org/10.5539/ijbm.v8n10p81

De Bruijn, H. (2002). Managing Performance in the Public Sector. London, United Kingdom: Routledge.

Ferlie, E. (1992). The creation and evolution of quasi markets in the public sector: A problem for strategic management. Strategic Management Journal, 13(S2), 79-97. http://dx.doi.org/10.1002/smj.4250130907

Ferlie, E., \& Ongaro, E. (2015). Strategic Management in Public Services Organizations. Concepts, schools and contemporary issues. London: Routledge.

Garud, R., \& Van de Ven, A. (2006). Strategic Change Process. In A. Pettigrew, H. T., Whittington, R. (Eds.), Handbook of Strategy and Management (Chapter 10, pp. 206-231). London, UK: Sage.

Gerring, J. (2006). Case Study Research: Principles and Practices. Cambridge, Massachusetts: Cambridge University Press.

Hammerschmid, G., Van de Walle, S., Andrews, R., \& Bezes, P. (2016). Public Administration Reforms in Europe: The View from the Top. Cheltenham, UK: Edward Elgar Publishing.

Hancock, D. R., \& Algozzine, R. (2006). Doing Case Study Research: A Practical Guide for Beginning Researchers. New York: Teachers College Press.

Hatry, P. H. (2006). Performance Measurement: Getting Results (Second Edition). Washington, District of Columbia USA: The Urban Institute Press. 
Hood, C. (1991). A public management for all seasons? Public Administration, 69(1), 3-19. https://doi.org/10.1111/j.1467-9299.1991.tb00779.x

Hood, C. (1995). The 'New Public Management' in the 1980s: Variations on a theme. Accounting Organization and Society, 20(2-3), 93-109. https://doi.org/10.1016/0361-3682(93)E0001-W

Hossan, C. G., McNeil, N., \& Brown, D. (2011). The dynamics of change in eService implementation: the case of Australian Local Government. International Journal of Business and Management, 6(11), 47-56. http://doi.org/10.5539/ijbm.v6n11p47

Kaplan, R. S. (1998). Innovation Action Research: Creating New Management Theory and Practice. Journal of Management Accounting Research, 10, 89-118.

Kearney, C., \& Meynhardt, T. (2016). Directing Corporate Entrepreneurship Strategy in the Public Sector to Public Value: Antecedents, Components, and Outcomes. International Public Management Journal, 19(4), 543-72. https://doi.org/10.1080/10967494.2016.1160013

Kotter, J. P. (1995). Leading Change: Why Transformation Efforts Fail. Harvard Business Review, March-April 73(2), 59-67. https://cb.hbsp.harvard.edu/resources/marketing/docs/95204f2.pdf

Kotter, J. P., \& Lawrence, P. R., (1974). Mayors in Action: Approaches to Urban Governance. John Wiley and Sons: New York, NY.

Kotter, J. P., \& Schlesinger, L. A. (1979). Choosing Strategies for Change. Harvard Business Review, March-April $57(2)$, 106-14. http://projects.iq.harvard.edu/files/sdpfellowship/files/day3_2_choosing_strategies_for_change.pdf?m=144 4230821

Kuhlmann, S., \& Wollmann, H. (2014). Introduction to comparative public administration: Administrative systems and reforms in Europe. Cheltenham, UK: Edward Elgar Publishing.

Lapsley, I. (2008). The NPM Agenda: Back to the Future. Financial Accountability \& Management, 24(1), 77-96. https://doi.org/10.1111/j.1468-0408.2008.00444.x

Leonard, D., \& Swap, W. (1999). When Sparks Fly: Igniting Creativity in Groups. Boston, Massachusetts: Harvard Business School Press.

Martin, S., \& Boaz, A. (2000). Public participation and citizen-centred local government: lessons from the Best Value and Better Government for Older People pilot programmes. Public Money and Management, 20(2), 47-53. https://doi.org/10.1111/1467-9302.00211

Miles, R. E., \& Snow, C. C. (1978). Organizational Strategy, Structure, and Process. New York: McGraw-Hill.

Mintzberg, H., Ahlstrand, B., \& Lampel, J. (2009). Strategy Safari (2nd ed.). Harlow, UK: FT Prentice Hall.

Montanari, J. R., \& Bracker, J. S. (1986). The Strategic Management Process at the Public Planning Unit Level. Strategic Management Journal, 7(3), 251-265. https://doi.org/10.1002/smj.4250070306

Moore, M. H., (1995). Creating Public Value. Strategic Management in Government. Cambridge, Mass, Harvard University Press.

Mussari, R. (1994). Accounting and Accountability in Italian Local Governments: Recent Changes and Challenger for the Future. Public Budgeting and Finance, 14(4), 54-70. https://doi.org/10.1111/1540-5850.01020

Osborne, D., \& Gaebler, T. (1992). Reinventing Government. Reading, Massachusetts: Addison Wesley.

Padovani, E., \& Young, D. W. (2012). Managing Local Government: Designing Management Control Systems that Deliver Value. London, UK: Routledge.

Parrado, S., Van Ryzin, G.G., Bovaird, A., \& Löffler, E. (2013). Correlates of co-production: Evidence from a five-nation survey of citizens. International Public Management Journal, 16(1), 85-112. https://doi.org/10.1080/10967494.2013.796260

Pettigrew, A., Ferlie, E., \& McKee, L. (1992). Shaping Strategic Change. London, UK: Sage.

Pettigrew, A., Whipp, R. (1991). Managing Change for Competitive Success. Oxford, UK: Blackwell.

Pfeffer, J. (1998). The Human Equation: Building Profits by Putting People First. Boston, Massachusetts: Harvard Business School Press.

Pina, V., Lourdes, T., \& Yetano, A. (2011). The implementation of strategic management in local governments. 
An international Delphi study. Public Administration Quarterly, 35(4), 551-90. https://paq.spaef.org/article/1345/The-Implementation-of-Strategic-Management-in-Local-Governments-An -International-Delphi-Study

Poister, T. H. (2003). Measuring Performance in Public and Nonprofit Organizations. San Francisco, California USA: Jossey-Bass.

Pollitt, C. (2003). The Essential Public Manager. Philadelphia, Open University Press.

Pollitt, C., \& Bouckaert, G. (2011). Public Management Reform: A comparative analysis-new public management, governance, and the Neo-Weberian state. New York: Oxford University Press.

Pollitt, C., (2008). Time, policy, management: governing with the past. Oxford, UK: Oxford University Press.

Porter, M. E. (1996). What is Strategy? Harvard Business Review, 74(6), November/December, 2-19.

Pröhl, M., \& Heichlinger A. (2009). Taking the Pulse of European Public Administrations - Key Findings of the European Public Sector Award 2009, Maastricht, The Netherlands: European Institute of Public Administration. $\quad$ Retrieved from https://epsa2017.eu/files/repository/20170126093635_ResearchReport_web.pdf

Ragin, C. C. (1992). What Is a Case?: Exploring the Foundations of Social Inquiry. Cambridge, UK: Cambridge University Press.

Rainey, H., Backoff, R., \& Levine, C., (1976). Comparing public and private organizations. Public Administration Review, 36, 233-46. https://doi.org/10.2307/975145

Stake, R. E. (1995). The Art of Case Study Research. Thousand Oaks, California: Sage Publications.

Yin, R. K. (2002). Case Study Research: Design and Methods (3rd ed.). Thousand Oaks, California: Sage Publications.

Young, D. W. (2000). The Six Levers for Managing Organizational Culture. Business Horizons, 43(5) September-October, 19-28. https://doi.org/10.1016/s0007-6813(00)80005-1

Young, D. W. (2016). Management Control in Nonprofit Organizations (10th ed.). Cambridge, Massachusettts: The Crimson Press.

Young, D. W. (2017a). The Seven Leadership Levers Used by Successful Managers. Cambridge, Massachusetts: Harvard Business School Publications, Item TCG331.

Young, D. W. (2017b). Note on Conflict Management. Cambridge, Massachusetts: Harvard Business School Publications, Item TCG316.

\section{Notes}

Note 1. For details, see www.epsa2017.eu.

Note 2. The decision to include Tallinn (a capital city) in the research was made in order to increase the diversity of administration cultures included in the project. Estonia usually has been considered as a post communist Central and Eastern European administrative tradition, even though recent studies have located it within the Scandinavian model (Hammerschmid et al., 2016).

Note 3. City records and results of this research are contained in Bosse et al. (2013).

Note 4. For full details on each city’s strategy, see Bosse et al. (2013).

Note 5. The title is based on the city's rectangular grid, in German "quadrate".

Note 6 This is not a completely arbitrary classification. It is a variation on two related frameworks. See, for example, Bradach (1996) and Young (2017a). For a similar approach, see Young (2000).

\section{Copyrights}

Copyright for this article is retained by the author(s), with first publication rights granted to the journal.

This is an open-access article distributed under the terms and conditions of the Creative Commons Attribution license (http://creativecommons.org/licenses/by/4.0/). 